Article

\title{
Development of a Sequential Injection Analysis System for the Determination of Saccharin
}

\author{
Budi Wibowotomo ${ }^{1,2}$, Jong-Bang Eun ${ }^{1}$ and Jong Il Rhee ${ }^{3, *}$ \\ 1 Department of Food Science and Technology and Functional Food Research Center, Chonnam National \\ University, YongBong-Ro 77, Gwangju 61186, Korea; budiwee@yahoo.com (B.W.); jbeun@jnu.ac.kr (J.-B.E.) \\ 2 Department of Industrial Technology, The State University of Malang, Jl Semarang 5, \\ Malang 65145, Indonesia \\ 3 School of Chemical Engineering and Research Center for Biophotonics, Chonnam National University, \\ YongBong-Ro 77, Gwangju 61186, Korea \\ * Correspondence: jirhee@jnu.ac.kr; Tel.: +82-62-530-1847; Fax: +82-62-530-0846
}

Received: 28 October 2017; Accepted: 11 December 2017; Published: 12 December 2017

\begin{abstract}
Saccharin is a powerfully sweet nonnutritive sweetener that has been approved for food-processing applications within the range of $100-1200 \mathrm{mg} / \mathrm{kg}$. A simple, rapid, and cost-effective sequential injection analysis (SIA) technique was developed to determine the saccharin level. This method is based on the reaction of saccharin with p-chloranil in an ethanol medium with a hydrogen peroxide $\left(\mathrm{H}_{2} \mathrm{O}_{2}\right)$ acceleration, and the resultant violet-red compound was detected using a UV-Vis spectrophotometer at $\lambda_{\max }=420 \mathrm{~nm}$. To ascertain the optimal conditions for the SIA system, several parameters were investigated, including buffer flow rate and volume, p-chloranil concentration, and reactant volumes (saccharin, p-chloranil, and $\mathrm{H}_{2} \mathrm{O}_{2}$ ). The optimum setup of the SIA system was achieved with a buffer flow rate, buffer volume, and draw-up time of $1.2 \mathrm{~mL} / \mathrm{min}$, $2900 \mu \mathrm{L}$, and $\sim 145 \mathrm{~s}$, respectively. The optimal p-chloranil concentration is $30 \mathrm{mM}$, and the best reactant volumes, presented in an ordered sequence, are as follows: $30 \mu \mathrm{L}$ of $\mathrm{H}_{2} \mathrm{O}_{2}, 450 \mu \mathrm{L}$ of saccharin, and $150 \mu \mathrm{L}$ of p-chloranil. The optimized SIA configuration produced a good linear calibration curve with a correlation coefficient $\left(R^{2}=0.9812\right)$ in the concentration range of $20-140 \mathrm{mg} / \mathrm{L}$ and with a detection limit of $19.69 \mathrm{mg} / \mathrm{L}$. Analytical applications in different food categories also showed acceptable recovery values in the range of $93.1-111.5 \%$. This simple and rapid SIA system offers great feasibility for the saccharin quality control in food-product processing.
\end{abstract}

Keywords: p-chloranil; food-product processing; hydrogen peroxide; saccharin; sequential injection analysis

\section{Introduction}

Saccharin $\left(\mathrm{C}_{7} \mathrm{H}_{5} \mathrm{NO}_{3} \mathrm{~S}\right)$ is a powerfully sweet nonnutritive sweetener; it is a white crystalline powder with an intensely sweet taste [1] that is 300-500 times sweeter than sugar. Saccharin is characterized by its high solubility, stability, and bitter metallic aftertaste [2]. The excellent stability of saccharin during food processing makes it ideal for many different products. It is applied in a wide range of food products including baked goods, beverages, soft drinks, sugar preserves and confectioneries, vinegar, pickles and sauces, dairy products, fruit, vegetables, nut products, sugar-free jams and marmalades, and low-calorie preserves [3]. It is particularly useful in cases where heat processing is required (e.g., jams, canned products, etc.).

After saccharin was ruled out as a potential carcinogen, the extent of its application in food processing has increased. Prior to 1977, before the publication of the additional studies that failed to support the initial assessments of the carcinogenic effects of saccharin, the United States Food and Drug Administration (US FDA) approved a prohibitionary action regarding the use of sodium 
saccharin $\left(\mathrm{C}_{7} \mathrm{H}_{5} \mathrm{NO}_{3} \mathrm{~S}\right)$ in dietary products and drugs, which was later repealed [4]. Further, the European Union (EU) via the European Scientific Committee for Food thoroughly assessed the safety of saccharin, considering its relevance in economic and social terms and the limitation of its content in foodstuffs, before it authorized the addition of saccharin to food products and beverages. Presently, however, sodium saccharin is approved in more than 90 countries globally and is widely used in many pharmaceutical and dietary products despite an ongoing controversy regarding its safety [5]. The acceptable daily intake (ADI) values that have been declared for saccharin by the United Nations (UN) Joint Food and Agriculture Organization FAO/World Health Organization (WHO) Expert Committee on Food Additives (JECFA) are within the body-mass range of 0-5 mg/kg [6]. The maximum residue levels (MRLs) of saccharin in different foods have been set within the range of $80-2500 \mathrm{mg} / \mathrm{kg}$ [7]. Therefore, various analytical techniques have been applied to determine the saccharin concentrations in numerous pharmaceutical and dietary products. High-performance liquid chromatography (HPLC) has been widely used for the determination of saccharin levels [8-10], but this technique requires expensive equipment and a complex sample pretreatment.

In recent years, flow injection analysis (FIA) has received much attention as an advanced analytical procedure. The several distinct advantages of this technique are in terms of its simplicity, cost performance, flexibility, and rapidity [11]. Saccharin concentration has been determined using FIA systems with many different analytical techniques. Saccharin has been precipitated as a mercurous saccharinate, and the mercurous cation was then potentiometrically measured using a silver (Ag)-wire coated with a mercury film. An FIA system consisting of an Ag-wire electrode was developed for the measurement of saccharin concentrations within the range of $2-10 \mathrm{mM}$ and at the sampling frequency of $601 / \mathrm{h}$ [12]. The precipitation reaction of $\mathrm{Ag}(\mathrm{I})$ ions with saccharin has been used to develop an FIA with a merging zone for the determination of saccharin concentration within the range of 2.4-9.64 g/L [13]. An atomic-absorption spectrometry was coupled with an FIA system for the determination of the saccharin concentration, where a continuous flow-manifold-based Ag-ion precipitation was used. The FIA method allows for the determination of the saccharin concentration in the range of $5-75 \mu \mathrm{g} / \mathrm{mL}$ and with a rate of ca. 20 samples/h [14]. In addition, an integrated solid-phase spectrophotometer-FIA method was developed based on an on-line aspartame preconcentration and a separation from the saccharin in a sweetener mixture. With a sampling frequency of $101 / \mathrm{h}$, the applicable saccharin concentration range is from $1.0-200.0 \mu \mathrm{g} / \mathrm{mL}$ [15].

The sequential injection analysis (SIA) system, however, is advantageous over the FIA method owing to its versatility and reliability along with its low frequency of maintenance [11]. Further, the potential of the SIA technique means that its operability can be fully automated, with a computer-based control for the aspiration or dispensation of samples and reagents. With respect to food applications, greatly advantageous SIA-system characteristics have been offered, including an easy adaptation to different analytical situations without the need for a physical reconfiguration, an automated sample injection, and a controlled dispersion. The SIA system allows for a choice of different types of liquid driver, a reproducible timing, a great capacity in relation to the solution-handling operations, and it is more flexible for its application in stopped-flow and reversed-flow operations [16,17]. To our knowledge, however, an automated determination of the saccharin concentration for which a SIA system is employed has not been reported; therefore, a simple and rapid SIA method for a quantitative determination of the saccharin concentration in food-product samples is proposed in the present paper. This method is based on the reaction of saccharin with p-chloranil in an ethanol medium together with a hydrogen peroxide $\left(\mathrm{H}_{2} \mathrm{O}_{2}\right)$ acceleration, whereby a violet-red compound is produced. The SIA system offers great feasibility regarding the determination of the saccharin concentration as it is simple, rapid, and economical; furthermore, it can be used for the quality control of nonnutritive sweeteners in food products. 


\section{Materials and Methods}

\subsection{Reagents}

All of the chemicals used in this study were of analytical grade. The saccharin stock solution $\left(\mathrm{C}_{7} \mathrm{H}_{4} \mathrm{NNaO}_{3} \mathrm{~S} \cdot 2 \mathrm{H}_{2} \mathrm{O}, 10 \mathrm{mM}\right)$ was prepared by dissolving $0.1206 \mathrm{~g}$ of sodium saccharin in $10 \mathrm{~mL}$ of absolute ethanol via a 15-min stirring that was followed by diluting to $50 \mathrm{~mL}$ with the same solvent. A 20-mM p-chloranil (Sigma Co., St. Louis, MO, USA) solution was prepared daily by dissolving $0.123 \mathrm{~g}$ of $\mathrm{p}$-chloranil in $25 \mathrm{~mL}$ of acetone (Mallinckrodt Co., St. Louis, MO, USA). A H $\mathrm{H}_{2}$ solution $(7.10 \mathrm{M})$ was prepared from a $30 \% \mathrm{H}_{2} \mathrm{O}_{2}$ concentrate (Merck Co., Darmstadt, Germany) via a convenient dilution in the ethanol (Mallinckrodt Co., St. Louis, MO, USA). A sodium phosphate-buffer solution $(200 \mathrm{mM})$ was used as the carrier solution.

\subsection{Sample Preparation}

An aliquot of 1.0 or $2.0 \mathrm{~g}$ or $\mathrm{mL}$ of food was transferred to a 50-mL Erlenmeyer flask. Then, $15 \mathrm{~mL}$ of ethanol was added to the flask, followed by a stirring of the mixture for $15 \mathrm{~min}$ and a filtration using the Whatman No. 41 paper (Sigma-Aldrich Co., Seoul, Korea). After the repetition of this step (15 mL of ethanol, $15 \mathrm{~min}$ ) and a third extraction (10 mL of ethanol, $5 \mathrm{~min}$ ) for a total of $40 \mathrm{~mL}$ of the solvent, the filtrate was collected and evaporated until $10 \mathrm{~mL}$ remained, and this remaining amount was then cooled in an ice bath for $5 \mathrm{~min}$. Finally, the resultant solution was filtered, transferred to a volumetric flask of $25 \mathrm{~mL}$, and then diluted to the $25-\mathrm{mL}$ volumetric indicator mark using the same solvent.

\subsection{The SIA System}

Figure 1 shows the SIA system that was used to measure the saccharin contents. It consists of a Cavro syringe pump (Tecan Group Ltd., Männedorf, Switzerland), a series port electrical selection valve (Knauer GmbH, Köln, Germany), and a fiber optic spectrophotometer (Model S2000; Ocean Optics Inc., Largo, FL, USA) connected to a flow-through quartz cell with an inner volume of $450 \mu \mathrm{L}$ and an optical path length of $10 \mathrm{~mm}$ (Hellma GmbH, Müllheim, Germany), and a deuterium-tungsten lamp (DH-2000, Ocean Optics Inc., Westfield, MA, USA) with two 2-m-long optical fibers with a fiber diameter of $200 \mu \mathrm{m}$. A double syringe pump was employed to increase the systemic speed-up capacity. Pump 1 was equipped with a 5-mL syringe that drew up the carrier buffer solution and pushed the reagent-sample mixture within the holding coil to the reaction coil. The holding and reaction coils were twisted from a PEEK tube ( $1 \mathrm{~mm}$ i.d. and $1.6 \mathrm{~mm}$ o.d.) for a good dispersion of the reagents and the sample. The absorbance of the violet-red compound solution was detected at $420 \mathrm{~nm}$. The control of the system was accomplished using a personal computer (PC) equipped with the PCI-6024E analog-to digital (A/D) interface board (National Instruments Co., Seoul, Korea). The software used for the data acquisition and the system control was written using the graphical programming language, LabVIEW $^{\mathrm{TM}}$ (vers. 6.1, National Instruments Co., Seoul, Korea). The operating sequence of the SIA system is described in Table 1. The cycle starts with the drawing up of the carrier buffer solution to the holding coil. Sequentially, the ethanol, hydrogen peroxide, and p-chloranil reagents were drawn up along with the sample into the holding coil. By the process of flow reversal, the stack zones were directed to the reaction coil and the detector. The passage of the colored product through the flow-through cell resulted in a transient signal that was recorded as the absorbance at $420 \mathrm{~nm}$, which was proportional to the saccharin concentration. 


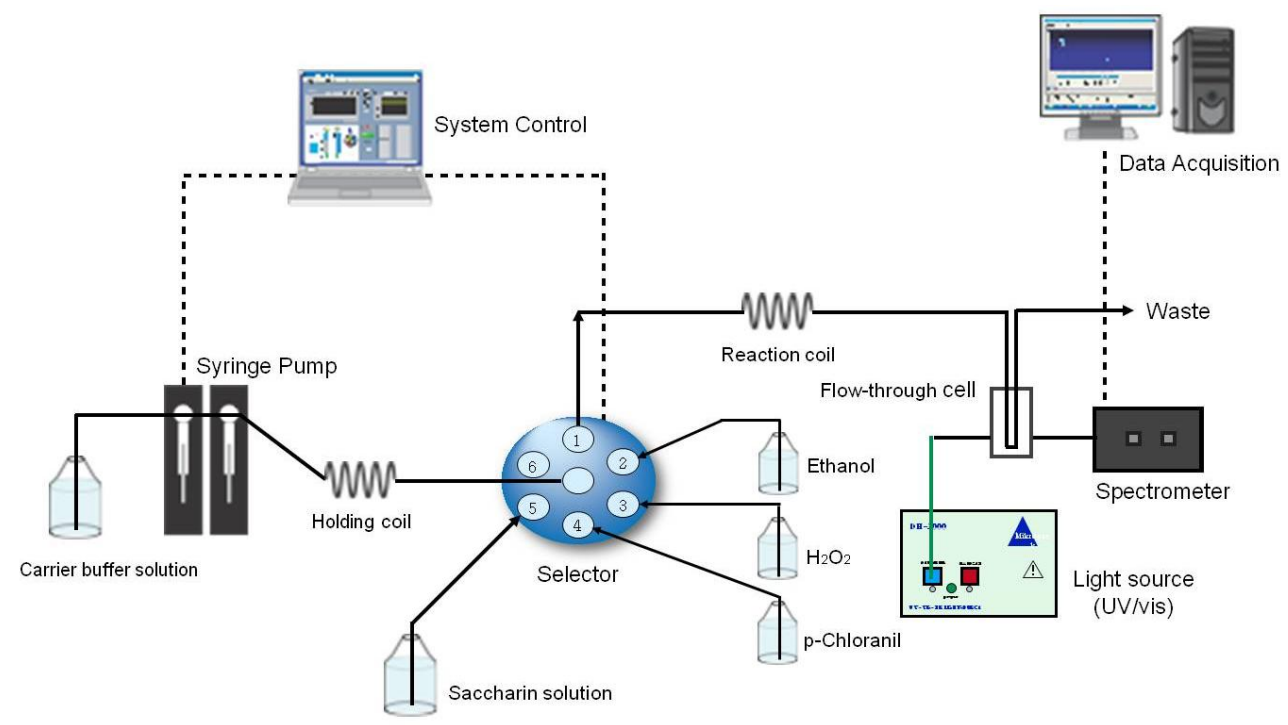

Figure 1. Schematic diagram of an sequential injection analysis (SIA) system for the determination of the saccharin concentration.

Table 1. Operating sequence of the SIA system for the determination of saccharin concentration.

\begin{tabular}{|c|c|c|c|c|}
\hline Time (s) & Pump 1 & Pump 2 & Valve & Description \\
\hline 0 & \multirow{3}{*}{$\begin{array}{l}\text { Reverse } \\
\text { Off }\end{array}$} & Off & & Drawn up carrier buffer solution \\
\hline 30 & & & Position 2 & Pump-stop, select solvent \\
\hline 35 & & Reverse & Position 2 & Drawn up solvent (ethanol) \\
\hline 68 & & Off & Position 1 & $\begin{array}{l}\text { Pump-stop, select assay line } \\
\text { (to } \mathrm{HC}=\text { holding coil) }\end{array}$ \\
\hline 73 & & Reverse & Position 3 & Drawn up reagent $1\left(\mathrm{H}_{2} \mathrm{O}_{2}\right)$ \\
\hline 89 & & Off & Position 1 & $\begin{array}{l}\text { Pump-stop, select assay line } \\
\text { (to } \mathrm{HC}=\text { holding coil) }\end{array}$ \\
\hline 94 & & Reverse & Position 4 & Drawn-up reagent 2 (p-chloranil) \\
\hline 116 & & Off & Position 1 & $\begin{array}{l}\text { Pump-stop, select assay line } \\
\text { (to } \mathrm{HC}=\text { holding coil) }\end{array}$ \\
\hline 121 & & Reverse & Position 5 & Drawn-up sample solution (saccharin) \\
\hline 132 & & Off & Position 1 & Pump-stop \\
\hline 137 & Forward & & Position 1 & $\begin{array}{l}\text { Pump stack of zones to the reactor } \\
\text { (RC = reaction coil) and detector }\end{array}$ \\
\hline 282 & Off & & & Pump-stop \\
\hline 287 & & Forward & Position 1 & $\begin{array}{l}\text { Pump stack of zones to the reactor } \\
(\mathrm{RC}=\text { reaction coil) and detector }\end{array}$ \\
\hline 332 & & Off & & Pump-stop \\
\hline 337 & & & Position 2 & Return to starting position \\
\hline
\end{tabular}

\subsection{Construction of the Calibration Curves}

Aliquots of saccharin stock solution (comprising saccharin concentrations from 50-600 mg/L) were placed on the sample valve, parallel to the ethanol, $20 \mathrm{mM} \mathrm{p}$-chloranil, and $0.50 \mathrm{~mL}$ of the $\mathrm{H}_{2} \mathrm{O}_{2}$ $(7.10 \mathrm{M})$, as described in Figure 1. Then, the SIA system was run according to the operating sequence in Table 1, (i.e., the setup conditions are a buffer flow rate of $1.6 \mathrm{~mL} / \mathrm{min}$, a buffer volume of $2400 \mu \mathrm{L}$, and the absorbance that was measured at $420 \mathrm{~nm}$ ). The calibration curves were prepared by plotting the absorbance against saccharin concentrations. 


\subsection{Reference Method}

For the assessment of the saccharin contents, aliquots of each sample were analyzed via the HPLC method that is described by Weinert et al. [18]. The HPLC system used consists of the Jasco liquid chromatography (Jasco Co., Easton, MD, USA) equipped with the Jasco PU-980 pump, an UV-Vis detector set to $254 \mathrm{~nm}$, and the Rheodyne 20- $\mu \mathrm{L}$ injector. The Phenomenex LC-18 analytical column with the parameters of $250 \mathrm{~mm} \times 4.6 \mathrm{~mm}$ (i.d.) (Phenomenex Co., Torrance, CA, USA) was used with packing material of a $5-\mu \mathrm{m}$ particle size. The mobile-phase consisted of a mixture of $20 \%$ $(v / v)$ reagent-grade glacial acetic acid in water, which was buffered to a $\mathrm{pH} 3.0$ using a saturated sodium acetate solution. Before the injection, the samples were filtered through the Millex-HV 0.45- $\mu \mathrm{m}$ membrane filter (Millipore Co., Temecula, CA, USA) and this was followed by an ultra-sonication. A calibration curve was also prepared using a standard concentration between 50 and $600 \mathrm{mg} / \mathrm{L}$.

\section{Results and Discussion}

The violet-red color development is based on the rapid formation of the complexes that is the result of the reaction of saccharin with p-chloranil ( $\pi$ acceptor) in the presence of $\mathrm{H}_{2} \mathrm{O}_{2}$ [18]. Gotardo et al. [19] also stated that the molecular interactions between the electron donors and the acceptors are generally associated with the formation of intensely colored charge-transfer complexes and radical ions, which absorb the radiation in the visible region of the spectrum $(\lambda=420 \mathrm{~nm})$, as shown in Figure 2. The spontaneous formation of the violet-red color from the yellow appearance of the p-chloranil upon the reaction with the saccharin is sufficient evidence of the formation of a charge-transfer complex. This reaction is markedly accelerated by the presence of $\mathrm{H}_{2} \mathrm{O}_{2}$.

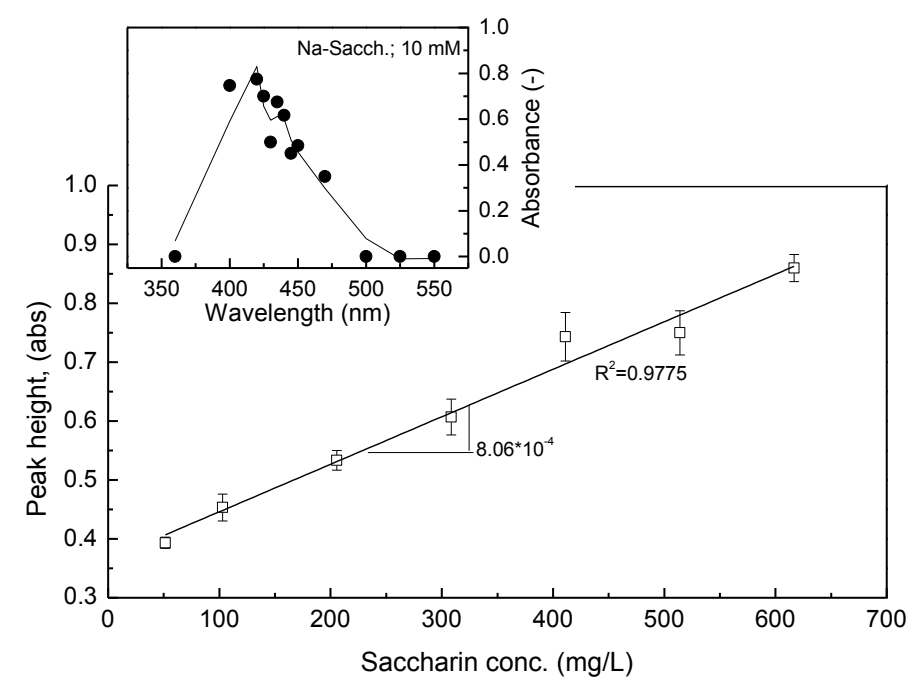

Figure 2. Linear calibration curve of saccharin under reference operating conditions (buffer flow rate and volume of $1.6 \mathrm{~mL} / \mathrm{min}$ and $2400 \mu \mathrm{L}$, respectively; $975 \mu \mathrm{L}$ of ethanol; $75 \mu \mathrm{L}$ of $\mathrm{H}_{2} \mathrm{O}_{2}(7.10 \mathrm{M}) ; 300 \mu \mathrm{L}$ of p-chloranil (20 mM); $150 \mu \mathrm{L}$ of saccharin).

\subsection{Characterization of the Saccharin-SIA System}

The preliminary calibration curve of saccharin is presented in Figure 2. A considerably effective analytical curve $\left(R^{2}=0.9775\right)$ was obtained when the SIA system was run to measure the peak heights of seven standard saccharin solutions in the concentration range of 50.0-600.0 mg/L. The SIA system consists of the following reference conditional setup: (a) the buffer flow rate and volume are $1.6 \mathrm{~mL} / \mathrm{min}$ and $2400 \mu \mathrm{L}$, respectively; and (b) the sequential order is $975 \mu \mathrm{L}$ of ethanol, $75 \mu \mathrm{L}$ of $\mathrm{H}_{2} \mathrm{O}_{2}$ $(7.10 \mathrm{M}), 300 \mu \mathrm{L}$ of p-chloranil $(20 \mathrm{mM})$, and then $150 \mu \mathrm{L}$ of saccharin. Furthermore, to improve the correlation efficiency and achieve a zero point-crossing line by as much as possible, it was necessary to 
fix several of the treatments including the buffer flow rate and volume, the p-chloranil concentration, and the reactant volume (p-choranil and $\mathrm{H}_{2} \mathrm{O}_{2}$ ).

The volumetric flow rate is a key parameter that has a marked influence on the dispersion zone in a SIA manifold [16,20]. Figure 3a shows the effects of the buffer flow rate and volume on the peak height during the measurements of saccharin concentration. The highest peak height was achieved with the buffer flow rate of $1.2 \mathrm{~mL} / \mathrm{min}$ and the buffer volume of $2900 \mu \mathrm{L}$, and the draw-up time of this setup is $\sim 145 \mathrm{~s}$. Weinert et al. [18] used a simplified spectrophotometric method for a routine analysis of the saccharin concentration in commercial non-caloric sweeteners, reporting that a complete color development was attained after $8 \mathrm{~min}$, while the color stability lasted for $20 \mathrm{~min}$.
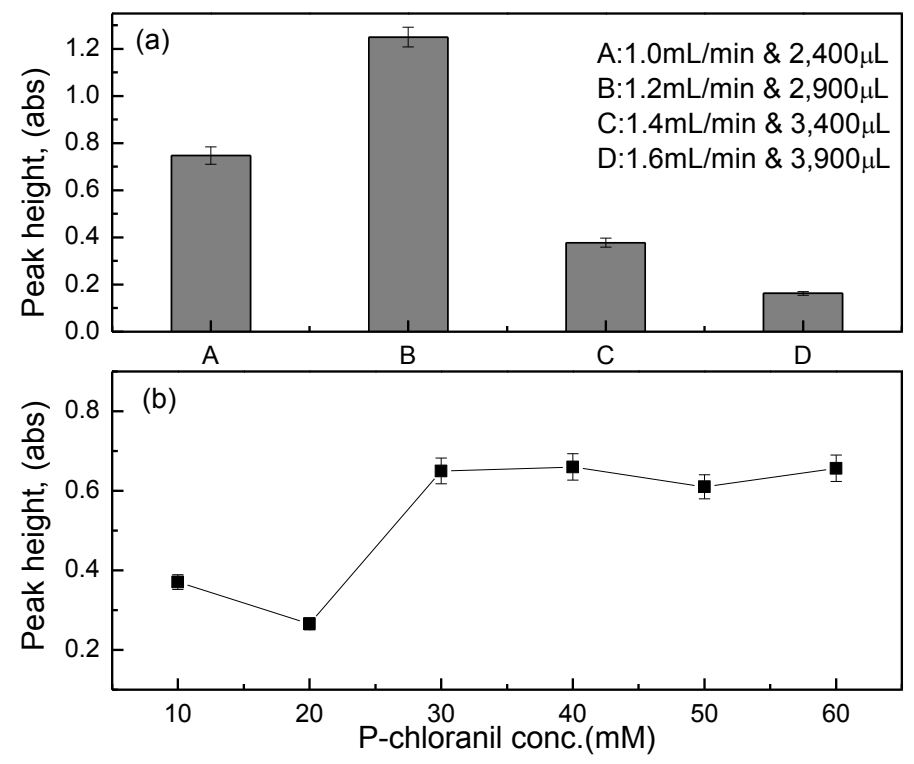

Figure 3. (a) Effects of the buffer flow rate and volume; and (b) effects of the p-chloranil concentration on the saccharin-SIA system under reference operating conditions with $10 \mathrm{mM}$ sodium saccharin.

The effects of the p-chloranil concentrations on the peak height during the saccharin measurements are described in Figure 3b. The optimal p-chloranil concentration was determined as $30 \mathrm{mM}$, even though the resultant peak heights are slightly lower than those at the concentrations of 50 and $60 \mathrm{mM}$. Based on several runs of the SIA system, a p-chloranil concentration that is more than $30 \mathrm{mM}$ caused the formation of microparticles in the flow-through cell. This p-chloranil concentration is admittedly very high, compared with $4 \mathrm{mM}$ that was reported by Weinart et al. [18]; however, it is considered as reasonable for a sufficiently short reaction time. Ruzicka and Hansen [21] also ruled that a good dispersion zone could be achieved with either the use of a high reagent concentration or an increasing of the injected sample volume.

The effects of the reactant volumes on the peak height during the measurements of saccharin concentrations are described in Figure 4. The optimal sample (saccharin) volume for the yielding of a high peak height is $900 \mu \mathrm{L}$, as shown in Figure 4a. In comparison with the p-chloranil volume of $300 \mu \mathrm{L}$, it could be assumed that the appropriate volume ratio of the sample (saccharin) to p-chloranil is 3 to 1. Ruzicka and Hansen [21] stated that a powerful way to change the dispersion to increase the peak height and sensitivity is the increasing of the volume of the injected sample solution. 

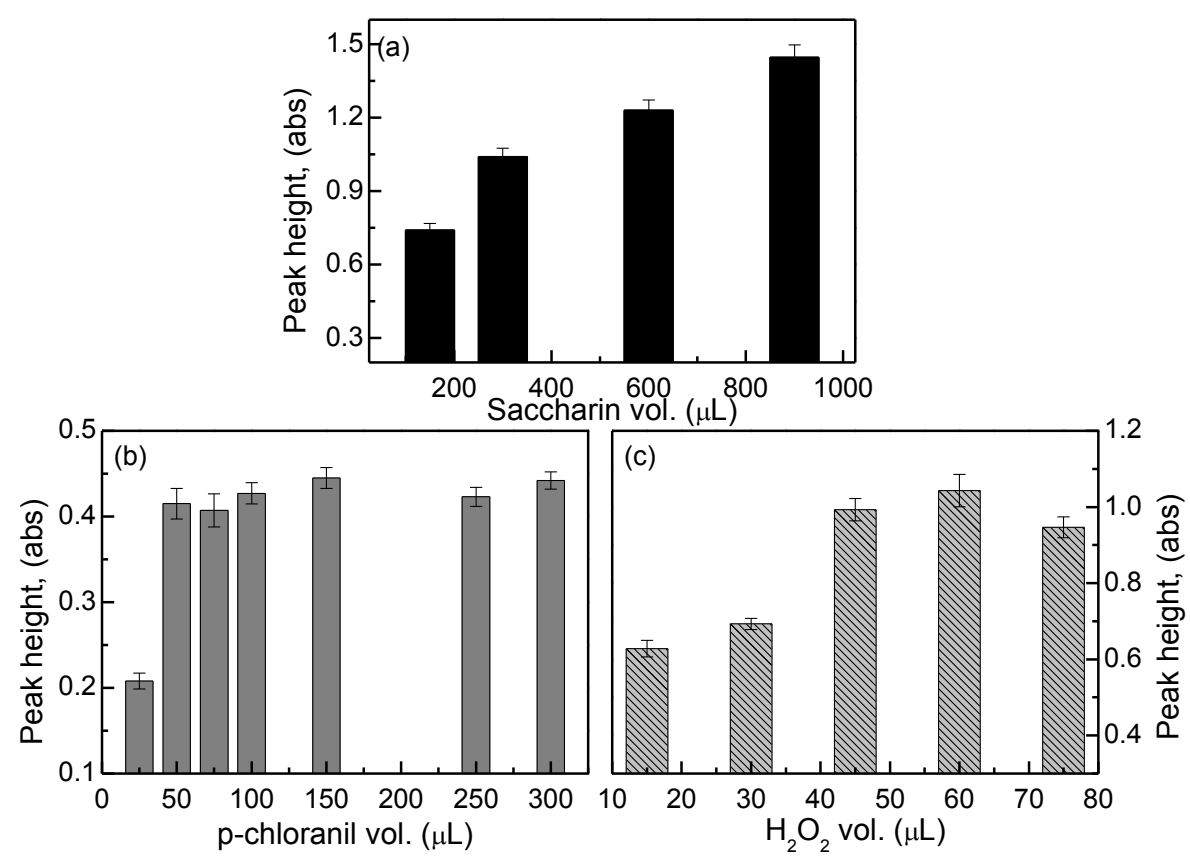

Figure 4. Effects of the reactant volumes on a saccharin-SIA system under reference operating conditions: (a) saccharin volume; (b) p-chloranil volume; and (c) hydrogen peroxide $\left(\mathrm{H}_{2} \mathrm{O}_{2}\right)$ volumes.

Regarding the effects of the p-chloranil volume that are shown in Figure $4 b$, the optimal value was determined as $150 \mu \mathrm{L}$, even though its peak height did not differ from the peak heights of the volumes ranging from $50-300 \mu \mathrm{L}$. The main consideration for this decision is the smallest relative standard deviation (RSD) that was produced by the p-chloranil volume of $150 \mu \mathrm{L}$. The volume of $150 \mu \mathrm{L}$ was also selected because its correlation seemed to be positive based on the previous tests on the effects of the p-chloranil concentration on the peak height; that is, this volume would be influential on the consumption of the p-chloranil volume. Another consequence is the subsequent use of a saccharin volume of $450 \mu \mathrm{L}$ that is in consideration of the optimal volume ratio of 3 to 1 . Figure $4 \mathrm{c}$ shows that significantly high peak heights were obtained with the $\mathrm{H}_{2} \mathrm{O}_{2}$ volumes of 15,30 , and $45 \mu \mathrm{L}$. With a similar consideration of the smallest $\mathrm{RSD}$, the $\mathrm{H}_{2} \mathrm{O}_{2}$ volume of $30 \mu \mathrm{L}$ was deemed as the optimal level. Moreover, for volumes that are less than $30 \mu \mathrm{L}$, the sequential injection-graphs are approximate (data not shown).

The developed analytical method was then validated by the construction of a calibration curve, whereby a limit of detection (LOD) was defined. Under the previously stated optimized operating conditions, the regression line was obeyed in the concentration range of $20-140 \mathrm{mg} / \mathrm{L}$ with a good correlation coefficient $\left(R^{2}=0.9812\right)$, as can be seen in Figure 5. The LOD ( $3 \cdot(\mathrm{Sy} / \mathrm{x}) /$ slope of calibration curve) is $19.69 \mathrm{mg} / \mathrm{L}$. The SIA method also showed high reproducibility with small values of RSD, that is, $6.4 \%$ at $40 \mathrm{mg} / \mathrm{L}, 7.3 \%$ at $100 \mathrm{mg} / \mathrm{L}$ and $6.8 \%$ at $140 \mathrm{mg} / \mathrm{L}$. The produced concentration range showed a considerable consistency with those presented in other studies of the flow injection method for the determination of saccharin concentration (i.e., $10-100 \mathrm{mg} / \mathrm{L} \mathrm{[10],} \mathrm{1.0-200.0} \mathrm{\mu g/mL} \mathrm{[15],} \mathrm{and}$ $5-75 \mu \mathrm{g} / \mathrm{mL}[14])$. 


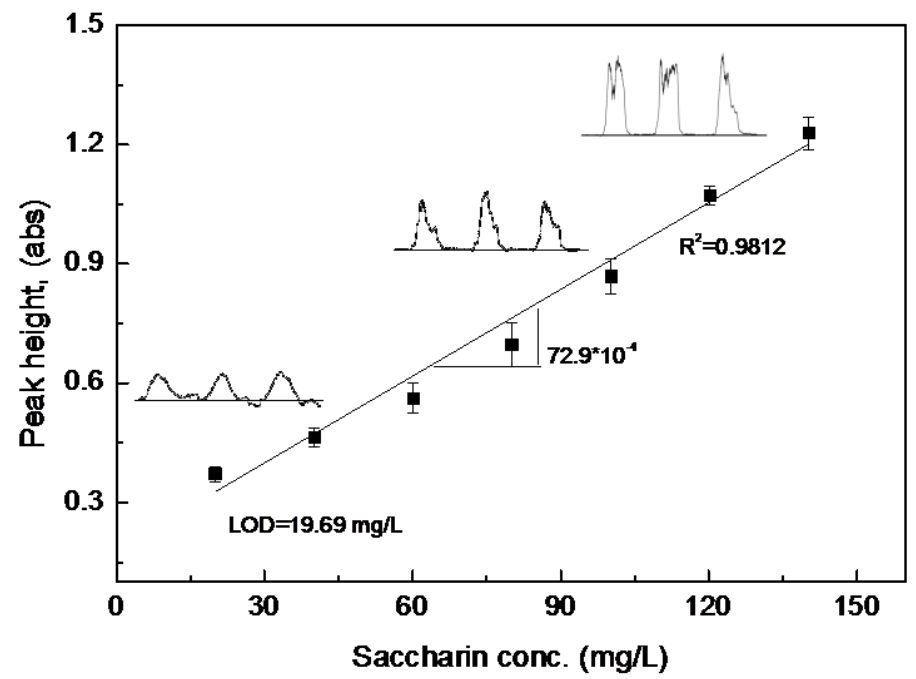

Figure 5. Calibration curve of a saccharin-SIA system under optimized operating conditions (buffer flow rate and volume of $1.2 \mathrm{~mL} / \mathrm{min}$ and $2900 \mu \mathrm{L}$, respectively; $870 \mu \mathrm{L}$ of ethanol; $30 \mu \mathrm{L}$ of $\mathrm{H}_{2} \mathrm{O}_{2}$ (7.10 M); $150 \mu \mathrm{L}$ of p-chloranil (30 mM) and $450 \mu \mathrm{L}$ of saccharin).

\subsection{Analytical Application}

The proposed SIA method was applied to determine the saccharin concentrations in different food products containing saccharin. The samples were analyzed using both the proposed SIA method and the HPLC method [18], and their results were then compared (Table 2). The average recovery percentages of the proposed SIA method are in the range from $93.1-111.5 \%$. Capitán-Vallvey et al. [15] yielded saccharin recovery percentages ranging from 100.3-105.3\%. Meanwhile, Kritsunankula et al. [10] and Yebra et al. [14] reported acceptable saccharin recovery percentages in several commercial liquid foods and sweetener mixtures, respectively, after the completion of flow injection determination processes.

Table 2. Determination of sodium saccharin in artificial sweeteners using the proposed SIA method and the high-performance liquid chromatography (HPLC) method.

\begin{tabular}{cccccc}
\hline \multirow{2}{*}{ Sample } & \multirow{2}{*}{ Labeled $^{\mathbf{a}}$} & \multicolumn{2}{c}{ Proposed SIA Method } & \multicolumn{2}{c}{ HPLC Method } \\
\cline { 3 - 5 } & & Found $^{\mathbf{d}}$ & Recovery (\%) $^{\mathbf{d}}$ & Found $^{\mathbf{d}}$ & Recovery (\%) $^{\mathbf{d}}$ \\
\hline Food sweetener $^{\mathrm{b}}$ & $50,000.0$ & $55,774.0 \pm 2946.0$ & $111.5 \pm 5.9$ & $46,170.7 \pm 616.0$ & $92.3 \pm 1.2$ \\
Food in brine $^{\mathrm{b}}$ & 500.0 & $496.1 \pm 33.7$ & $99.2 \pm 6.7$ & $554.3 \pm 79.0$ & $110.9 \pm 15.8$ \\
Soft drink 500 $^{\mathrm{c}}$ & 500.0 & $465.4 \pm 14.1$ & $93.1 \pm 2.8$ & $550.6 \pm 7.6$ & $110.1 \pm 1.5$ \\
Pudding 500 $^{\mathrm{c}}$ & 500.0 & $477.9 \pm 34.2$ & $95.6 \pm 6.8$ & $528.3 \pm 25.7$ & $105.7 \pm 5.1$ \\
Steamed-bread 500 $^{\mathrm{c}}$ & 500.0 & $535.0 \pm 74.0$ & $107.0 \pm 14.8$ & $517.56 \pm 36.0$ & $103.5 \pm 7.2$ \\
\hline
\end{tabular}

${ }^{a}$ Amount of sodium saccharin measured in $\mathrm{mg} / \mathrm{kg}$ for the solid samples and measured in $\mathrm{mg} / \mathrm{L}$ for the liquid samples. ${ }^{\mathrm{b}}$ Commercial food collected from local market. ${ }^{\mathrm{c}}$ Home-made samples spiked with $500 \mathrm{mg} / \mathrm{kg}$ of saccharin (Appendix). ${ }^{\mathrm{d}}$ Average \pm standard deviation (SD) of three determinations per sample.

\section{Conclusions}

A simple, rapid, and cost-effective sequential injection analysis (SIA) method was successfully optimized for the determination of saccharin $\left(\mathrm{C}_{7} \mathrm{H}_{5} \mathrm{NO}_{3} \mathrm{~S}\right)$ in food products. The optimal setup of this system occurred with a buffer flow rate of $1.2 \mathrm{~mL} / \mathrm{min}$ and a buffer volume of $2900 \mu \mathrm{L}$. The draw-up time of this setup is $\sim 145 \mathrm{~s}$. After an investigation of the effects of the p-chloranil concentration and the reactant volumes, the optimally ordered sequence of the reagent concentration and volumes is $870 \mu \mathrm{L}$ of ethanol, $30 \mu \mathrm{L}$ of $\mathrm{H}_{2} \mathrm{O}_{2}(7.10 \mathrm{M}), 150 \mu \mathrm{L}$ of p-chloranil $(30 \mathrm{mM})$, and $450 \mu \mathrm{L}$ of saccharin. This SIA configuration produced a good linear calibration curve with a correlation coefficient $\left(R^{2}=0.9812\right)$ in the saccharin concentration range of $20-140 \mathrm{mg} / \mathrm{L}$ and with a detection limit of $19.69 \mathrm{mg} / \mathrm{L}$. The analytical 
applications in the different food categories also showed acceptable saccharin recovery percentages in the range of $93.1-111.5 \%$.

Author Contributions: B.W. and J.-B.E. conceived and designed the experiments; B.W. performed experiments and analyzed the data. J.I.R. contributed analysis tools and wrote the paper.

Conflicts of Interest: The authors declare no conflict of interest.

\section{References}

1. Varzakas, T.; Labropoulos, A.; Anestis, S. Sweeteners: Nutritional Aspects, Applications, and Production Technology; CRC Press: Boca Raton, FL, USA, 2012.

2. Nabors, L.O.; Gelardi, A.E. Alternative Sweeteners; CRC Press: Boca Raton, FL, USA, 1991.

3. American Dietetic Association. Position of the American Dietetic Association: Use of nutritive and nonnutritive Sweeteners. J. Am. Diet. Assoc. 2004, 104, 255-275.

4. Wang, Y.; Xu, Z.L.; Xie, Y.Y.; Tian, Y.X.; Shen, Y.D.; Young, G.M.; Wang, H.; Lei, H.T.; Sun, Y.M. Development of polyclonal antibody-based indirect competitive enzyme-linked immunosorbent assay for sodium saccharin residue in food samples. Food Chem. 2011, 126, 815-820. [CrossRef]

5. European Commission. Directive 96/83/EC of the European Parliament and of the Council; European Commission: Brussels, Belgium, 1996; Volume 3.

6. FAO; WHO. Summary of Evaluations Performed by the Joint FAO/WHO Expert Committee on Food Additives (JECFA) 1956-1997 (First through Forty-Ninth Meetings) FAO \& WHO; ILSI Press: Washington, DC, USA, 1999.

7. CODEX Alimentarius Commission. Saccharin: Joint FAO/WHO Food Standards Programme. In Proceedings of the GSFA Online Updated up to the 38th Session of the Codex Committee, Geneva, Switzerland, 6-11 July 2015.

8. Lee, Y.; Kim, B.; Kim, J.; Ahn, S. Accurate quantification of saccharin using isotope dilution liquid chromatography mass spectrometry (ID-LC/MS). Mass Spectrom. Lett. 2011, 2, 37-40. [CrossRef]

9. Chang, C.-S.; Yeh, T.S. Detection of 10 sweetners in various foods by liquid chromatography/tandem mass spectrometry. J. Food Drug Anal. 2014, 22, 318-328. [CrossRef] [PubMed]

10. Kritsunankula, O.; Jakmunee, J. Simultaneous determination of some food additives in soft drinks and other liquid foods by flow injection on-line dialysis coupled to high performance liquid chromatography. Talanta 2011, 84, 1342-1349. [CrossRef] [PubMed]

11. Lee, S.H.; Sohn, O.J.; Yim, Y.S.; Han, K.A.; Hyung, G.W.; Chough, S.H.; Rhee, J.I. Sequential injection analysis system for on-line monitoring of 1-cysteine concentration in biological processes. Talanta 2005, 68, 187-192. [CrossRef] [PubMed]

12. Fatibello-Filho, O.; Nóbrega, J.A.; Guaritá-Santos, A.J.M. Flow injection potentiometric determination of saccharin in dietary products with relocation of filtration unit. Talanta 1994, 41, 731-734. [CrossRef]

13. Mendes, C.; Laignier, E.; Brigago, M.; Luccas, P.; Tarley, C. A simple turbidimetric flow injection system for saccharin determination in sweetener products. Chem. Pap. 2010, 64, 285-293. [CrossRef]

14. Yebra, M.C.; Gallego, M.; Valcárcel, M. Precipitation flow-injection method for the determination of saccharin in mixtures of sweeteners. Anal. Chim. Acta 1995, 308, 275-280. [CrossRef]

15. Capitán-Vallvey, L.F.; Valencia, M.C.; Arana-Nicolás, E.; García-Jiménez, J.F. Resolution of an intense sweetener mixture by use of a flow injection sensor with on-line solid-phase extraction: Application to saccharin and aspartame in sweets and drinks. Anal. Bioanal. Chem. 2006, 385, 385-391. [CrossRef] [PubMed]

16. Pérez-Olmos, R.; Soto, J.C.; Zárate, N.; Araújo, A.N.; Lima, J.L.F.C.; Saraiva, M.L.M.F.S. Application of sequential injection analysis (SIA) to food analysis. Food Chem. 2005, 90, 471-490. [CrossRef]

17. Laiwattanapaisala, W.; Kunanuvat, U.; Intharachutia, W.; Chinvongamornb, C.; Hannongbuac, S.; Chailapakuld, O. Simple sequential injection analysis system for rapid determination of microalbuminuria. Talanta 2009, 79, 1104-1110. [CrossRef] [PubMed]

18. Weinert, P.L.; Pezza, H.R.; De Oliveira, J.E.; Pezza, L. A simplified spectrophotometric method for routine analysis of saccharin in commercial noncaloric sweeteners. J. Agric. Food Chem. 2004, 52, 7788-7792. [CrossRef] [PubMed] 
19. Gotardo, M.A.; Lima, L.S.; Sequinel, R.; Rufino, J.L.; Pezza, L.; Pezza, H.R. A simple spectrophotometric method for the determination of methyldopa using $\rho$-chloranil in the presence of Hydrogen Peroxide. Eclet. Quim. 2008, 33, 7-12. [CrossRef]

20. Marshall, G.D. Sequential Injection Analysis. Ph.D. Thesis, University of Pretoria, Pretoria, South Africa, 1994.

21. Ruzicka, J.; Hansen, E.H. Flow-Injection Analysis, 2nd ed.; John Wiley \& Sons, Inc.: New York, NY, USA, 1998.

(C) 2017 by the authors. Licensee MDPI, Basel, Switzerland. This article is an open access article distributed under the terms and conditions of the Creative Commons Attribution (CC BY) license (http:/ / creativecommons.org/licenses/by/4.0/). 